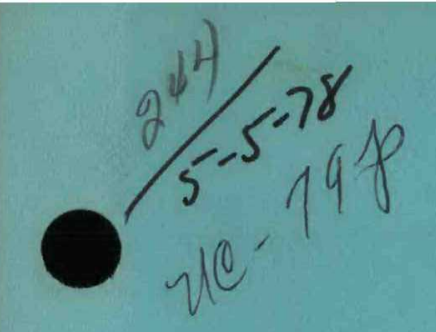

QUARTERLY TECHNICAL PROGRESS REPORT

\title{
REACTOR SAFETY
}

OCTOBER - DECEMBER 1977

DOE Research and Development Report

Prepared for the United States

Department of Energy

Division of Reactor Research and Technology, under Contract Number EY-76-C-03-0824 


\section{DISCLAIMER}

This report was prepared as an account of work sponsored by an agency of the United States Government. Neither the United States Government nor any agency Thereof, nor any of their employees, makes any warranty, express or implied, or assumes any legal liability or responsibility for the accuracy, completeness, or usefulness of any information, apparatus, product, or process disclosed, or represents that its use would not infringe privately owned rights. Reference herein to any specific commercial product, process, or service by trade name, trademark, manufacturer, or otherwise does not necessarily constitute or imply its endorsement, recommendation, or favoring by the United States Government or any agency thereof. The views and opinions of authors expressed herein do not necessarily state or reflect those of the United States Government or any agency thereof. 


\section{DISCLAIMER}

Portions of this document may be illegible in electronic image products. Images are produced from the best available original document. 


\title{
NOTICE
}

This report was prepared as an account of work sponsored by the United States Government. Neither the United States nor the United States Department of Energy, nor any of their employees, nor any of their contractors, subcontractors, or their employees, makes any warranty, express or implied, or assumes any legal liability or responsibility for the accuracy, completeness or usefulness of any information, apparatus, product or process disclosed, or represents that its use would not infringe privately owned rights.

\author{
Printed in the United States of America \\ Available from \\ National Technical Information Service \\ U.S. Department of Commerce \\ 5285 Port Royal Road \\ Springfield, Virginia 22151
}

Price: Printed Copy $\$ 4.50$ Microfiche $\$ 3.00$ 
AI-DOE-13223

LMFBR SAFETY

UC.79p

\section{QUARTERLY TECHNICAL PROGRESS REPORT}

REACTOR SAFETY

OCTOBER - DECEMBER 1977

The preceding Progress Report was AI-ERDA-13210

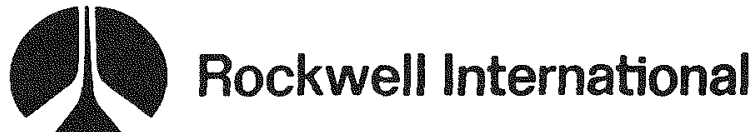

Atomics International Divisıon

8900 DeSoto Avenue

Canoga Park, Calıfornıa 91304 


\section{DISTRIBUTION}

This report has been distributed according to the category, "LMFBR Safety," as given in the Standard Distribution for Unclassified Scientific and Technical Reports, TID-4500. 


\section{CONTENTS}

\begin{tabular}{|c|c|c|c|c|}
\hline Program & $\begin{array}{c}\text { DOE } \\
\text { Task } \\
\text { No. }\end{array}$ & $\begin{array}{l}189 \\
\text { No. }\end{array}$ & Project Title & Page \\
\hline $\begin{array}{l}\text { Reactor } \\
\text { Safety }\end{array}$ & 28 & $\mathrm{SA} 002$ & Accident Debris Behavior & $\cdots$ \\
\hline
\end{tabular}

\section{TABLES}

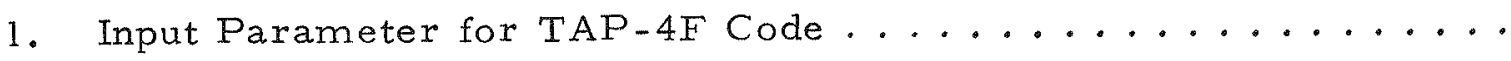

\section{FIGURES}

1. Multiple Bend Leak Path ..................... 6

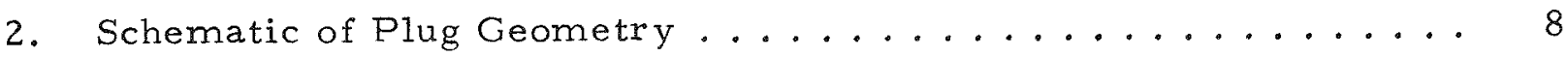

3. Data on Plugging Mass vs Duct Size ..................... 10

4. HTCA Plateout and Fallout Sampling Device............. 12

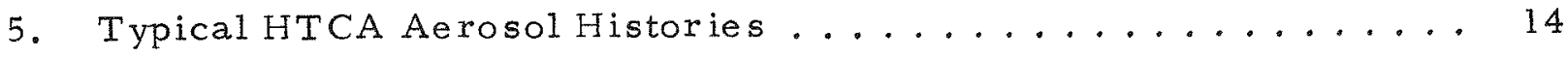

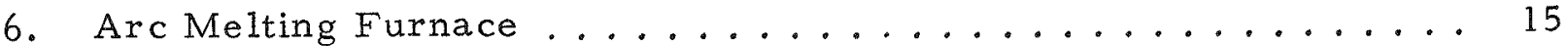

7. Crucible After Pouring $\mathrm{UO}_{2} \ldots \ldots \ldots \ldots \ldots \ldots$

8. Solidified $\mathrm{UO}_{2}$ Top $\mathrm{View}(\mathrm{Te}$ st $\mathrm{B}) \ldots \ldots \ldots \ldots$

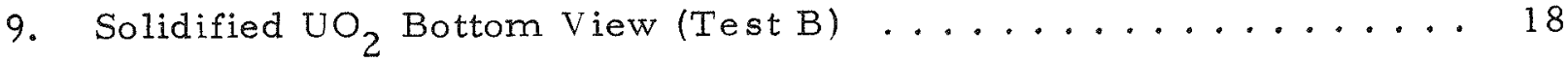

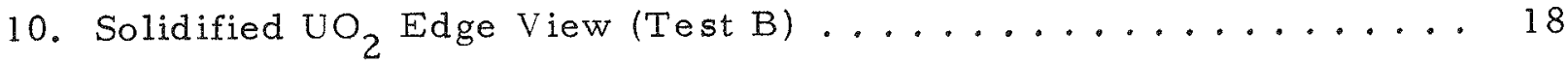

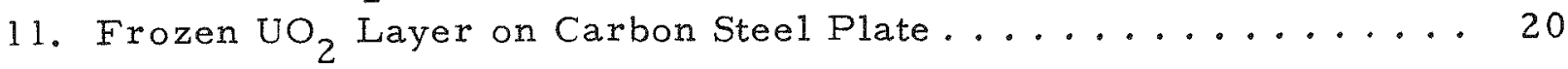

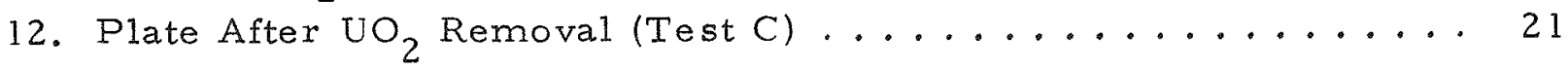

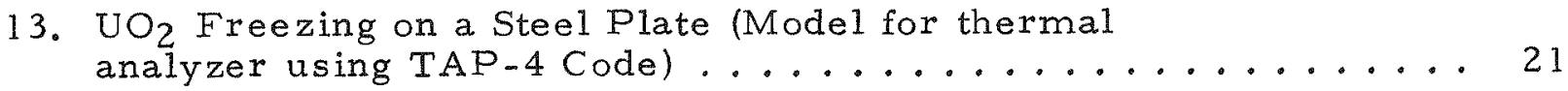

14. Temperature vs Time After Contact (TAP-4 simulation) ..... 24

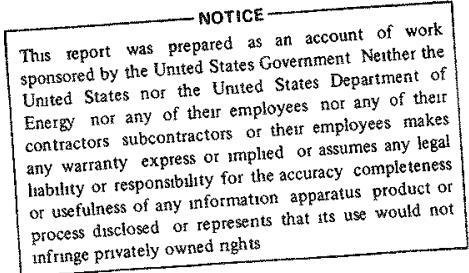

AI-DOE -13223 
Program: LMFBR Safety

ERDA Task: Task 28, Reactor Safety SA002: Accident Debris Behavior

Program Manager: R. W. Keaten

Project Manager: H. A. Morewitz

Reporting Period: October - December 1977 Category:

General Order: $09292 \quad$ Subaccount: $12000,12210,13100,189$ a Number: SA 002 $13200,14120,14121,14200,16100$, $17100,19000,21000,22000$

Principal Investigators: R. P. Johnson, C. T. Nelson, E. U. Vaughn, and C. Guderjahn

\section{PROJECT OBJECTIVES}

1) Conduct tests that will characterize the behavior of sodium oxide, fuel, fission product, and other aerosols as they might be generated by various postulated LMFBR accidents.

2) Determine by analysis and confirm by experiment the generation and transport of these aerosols with respect to source (location, type, and configuration), for the entire course of events associated with real and hypothetical accident conditions.

3) Conduct tests that will determine the effect of molten fuel on reactor structural or sacrificial material.

II. MAJOR ACCOMPLISHMENTS DURING REPORT PERIOD

A. SUBTASK C - AEROSOL LEAKAGE

1. Multiple Bend Leak Path

A multiple bend leak path was constructed to simulate the type of leak path that may exist in a reactor head seal. Tests are being performed to show that aerosols containing sodium combustion products, when passing through leak paths of this type, have large attenuation factors and quickly plug.

The multiple bend leak path, as shown in Figure 1, is composed of four leak paths plus connecting annuli. The leak path LPa represents a rotating 


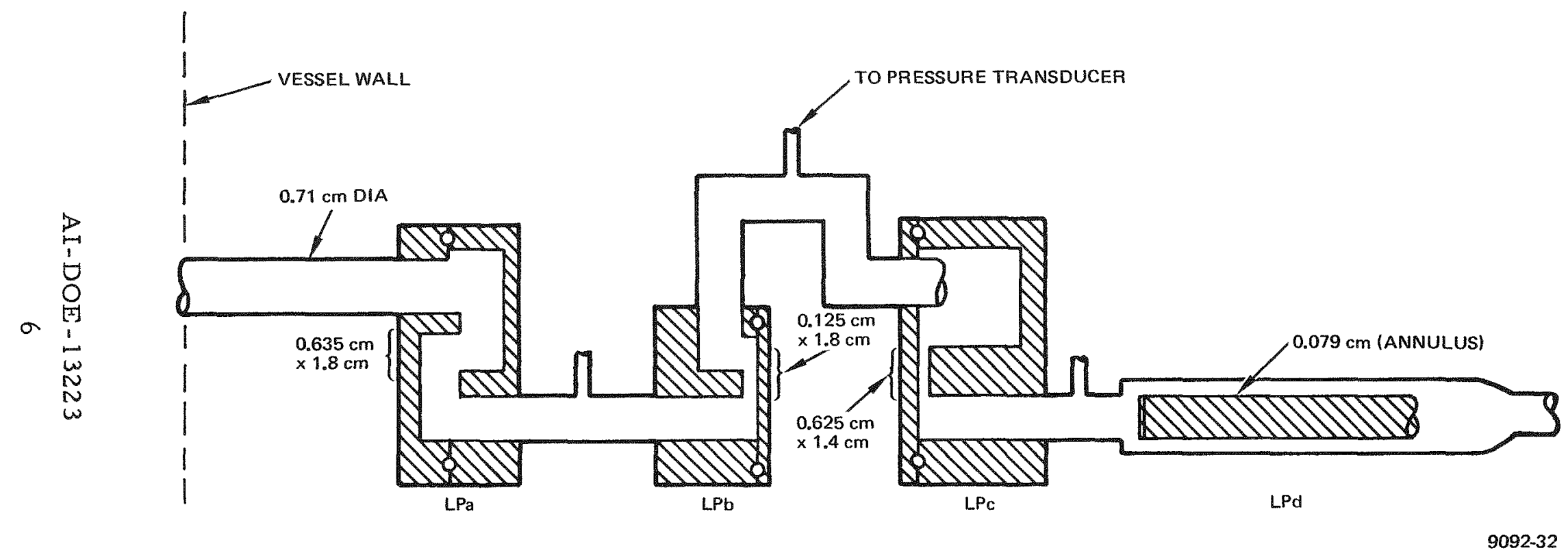

Figure 1. Multiple Bend Leak Path 
plug sodium seal in which the seal is void of sodium. Leak Paths LPb, LPc, and LPd represent the spacing that may occur at the lower margin ring assembly, dynamic (inflatable) seal, and upper margin seal (including the associated assembly), respectively.

A checkout test was conducted using the aerosol generator described in previous reports. An aerosol mixture $\left(\mathrm{Na}_{2} \mathrm{O}_{\mathrm{x}}\right.$ and $\left.\mathrm{Na}_{2} \mathrm{CO}_{3}\right)$ with a concentration of 15 to $20 \mu \mathrm{g} / \mathrm{cc}$ (sodium content) was generated for this test. The multiple bend leak plugged in $\sim 5$ min while passing $\sim 217$ liters of gas. Calculations showed that 3 to 4 grams of sodium (in the form of $\mathrm{Na}_{2} \mathrm{O}_{\mathrm{x}}+\mathrm{Na}_{2} \mathrm{CO}_{3}$ ) were required to plug the specimen. A pressure differential of $0.068 \mathrm{~atm}$ was maintained during the test.

When the leak path was disassembled, complete plugging at LPa, LPb and the annulus between was observed. The inlet annulus was nearly plugged. Very little aerosol was collected beyond $L P b$.

\section{Simple Model for Plugging of Ducts by Aerosol Deposits}

Experiments ${ }^{(1)}$ on the leakage of aerosols through capillaries indicate that complete, partial, or incipient plugging of the flow path by deposits of aerosol material plays a major role in reducing the inhalation hazard, both by decreasing the amount of escaping particulate matter and by increasing the size of the particle agglomerates. However, current theories ${ }^{(2)}$ of the deposition of aerosol particles during the flow through ducts ignore the modification of the geometry of the flow by the accumulation of material on the walls. An initial attempt to model this neglected feature is now presented.

The deposits observed are highly irregular in general configuration and dendritic in detailed structure. This complexity is also encountered in the problem of aerosol agglomeration where irregular dendritic agglomerates are replaced by structureless spheres with considerable success. (3) This modeling is adapted to the present problem by assigning a mean density, $\rho$, to the porous deposit while simplifying the geometry to a single growing plug that retains a fixed shape having rotational symmetry about the axis of a cylindrical duct (Figure 2). Use of a single plug reflects the tendency for a larger plug to grow more rapidly than a smaller plug by intercepting more of the flow. 


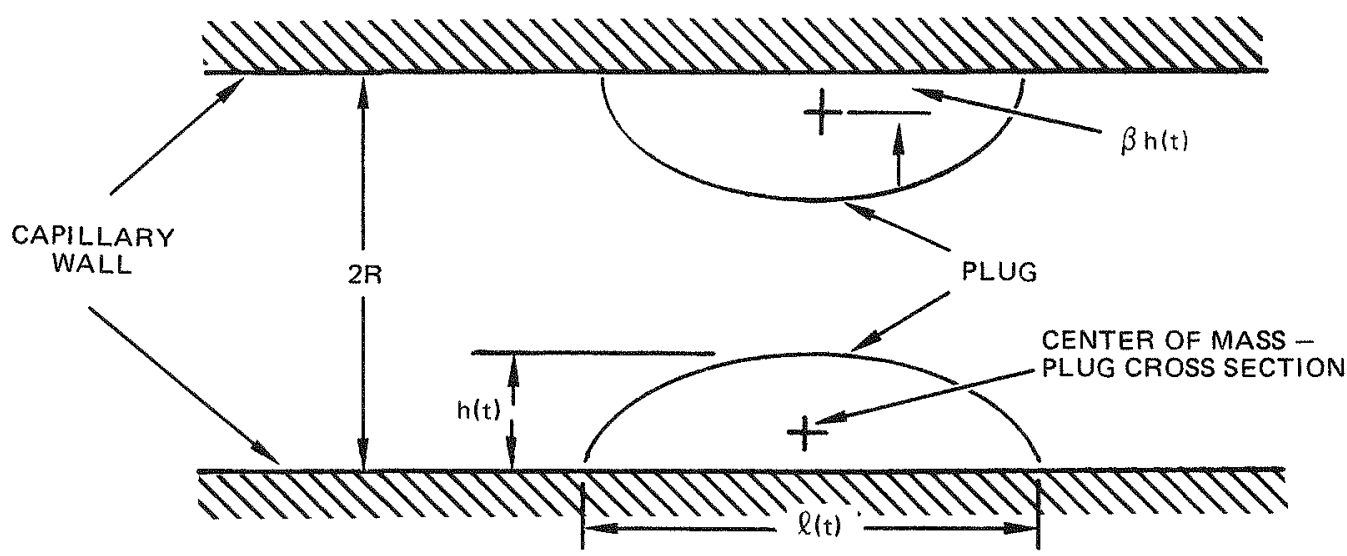

$9092-33$

Figure 2. Schematic of Plug Geometry

With these assumptions, the mass of the plug at any time, $M(t)$, is determined by the value at that time of any one geometrical parameter of the plug, together with the fixed radius of the duct, $R$. The parameter used is the greatest thickness of the deposit, denoted by $h(t)$. The area of a section of the plug by a plane through the duct axis is then a fixed multiple, $\alpha$, of $h^{2}(t)$, and the volume is the product of this area by the length of the circumference described by its center of mass as the plane rotates about the duct axis. The distance of that center of mass from the wall being another fixed multiple, $\beta$, of $h(t)$, the mass is

$$
M(t)=2 \pi \alpha \rho[R-\beta h(t)] h^{2}(t) .
$$

A mass balance can be derived by equating the rate of change of the mass obtained by differentiating Equation 1 to the deposition rate provided by suitable assumptions about the flow and deposition mechanisms. The suspended mass concentration of particulates is supposed to be an arbitrary function of time, $C(t)$. The volumetric flow rate through the duct may vary in time because of the changes in plug size and also for other reasons, and is accordingly denoted by $Q[t, h(t)]$. The ratio of the deposition rate to the interception $r$ ate that would result if the particles were moving on straight lines parallel to the axis is called the collection efficiency of the plug. It is assumed to depend on the ratio of plug height to duct radius, $h(t) / R$, but not on flow rate nor particle 
size, and is therefore denoted by $E[h(t) / R]$. These assumptions, with their implied neglect of the inertia of the particles, are not necessarily correct, but can be tested by comparing the properties of the model with experiments.

In terms of these functions, the deposition $r$ ate is expressed as

$$
\dot{M}=C(t) Q[t, h(t)] E[h(t) / R] \pi\left\{R^{2}-[R-h(t)]^{2}\right\} /\left\{\pi R^{2}\right\} .
$$

Here the product, $C(t) Q[t, h(t)]$, represents the rate at which particulate mass is carried past the plug by the flow and can be eliminated by using the total mass thus transported up to the time, $t$, as the independent variable instead of titself. Then Equations 1 and 2 give

$$
\begin{aligned}
& \mathrm{dM} / \mathrm{dm}=2 \pi \alpha \rho\left[2 \mathrm{Rh}(\mathrm{m})-3 \beta \mathrm{h}^{2}(\mathrm{~m})\right] \mathrm{dh} / \mathrm{dm}, \\
& \mathrm{dM} / \mathrm{dm}=\mathrm{E}[\mathrm{h}(\mathrm{m}) / \mathrm{R}]\left\{1-[1-\mathrm{h}(\mathrm{m}) / \mathrm{R}]^{2}\right\}
\end{aligned}
$$

respectively. Finally, taking $x=h / R$ as a new variable, the mass balance resulting from Equations 3 and 4 can be solved for $\mathrm{dm} / \mathrm{dx}$ in the form

$$
\mathrm{dm} / \mathrm{dx}=2 \pi \alpha \rho R^{3}\left(2 \mathrm{x}-3 \beta \mathrm{x}^{2}\right) /\left[\left(2 \mathrm{x}-\mathrm{x}^{2}\right) \mathrm{E}(\mathrm{x})\right]
$$

The total particulate mass, $\bar{m}$, transported past the plug before its growth blocks further passage of particulates, is obtained by integration of Equation 5 from $x=0$ to $x=1$, corresponding to growth of the plug from $h=0$ to $h=R$. The result is

$$
\bar{m}=2 \pi \alpha \rho R^{3} \int_{0}^{1} d x\left(2 x-3 \beta x^{2}\right) /\left[\left(2 x-x^{2}\right) E(x)\right] \text {. }
$$

Since the values of $\alpha, \beta$, and $\rho$, and the form of the function $E(x)$ remain unknown, the only useful content of Equation 6 is that

$$
\bar{m}=K R^{3},
$$


where the constant $K$ is unknown, but is independent of the concentration $C(t)$, the flow rate, $Q[t, h(t)]$, and the size of the particulates.

A preliminary test of Equation 7 is presented in Figure 3. The lower five points were obtained from experiments ${ }^{(1)}$ on sodium carbonate aerosols passing through smooth capillaries. The other two points represent "inadvertent experiments" in which investigations of cover-gas systems were inter rupted by blockages in the ducts. $(4,5)$ The empirical support for Equation 7 is seen to be modest but encouraging.

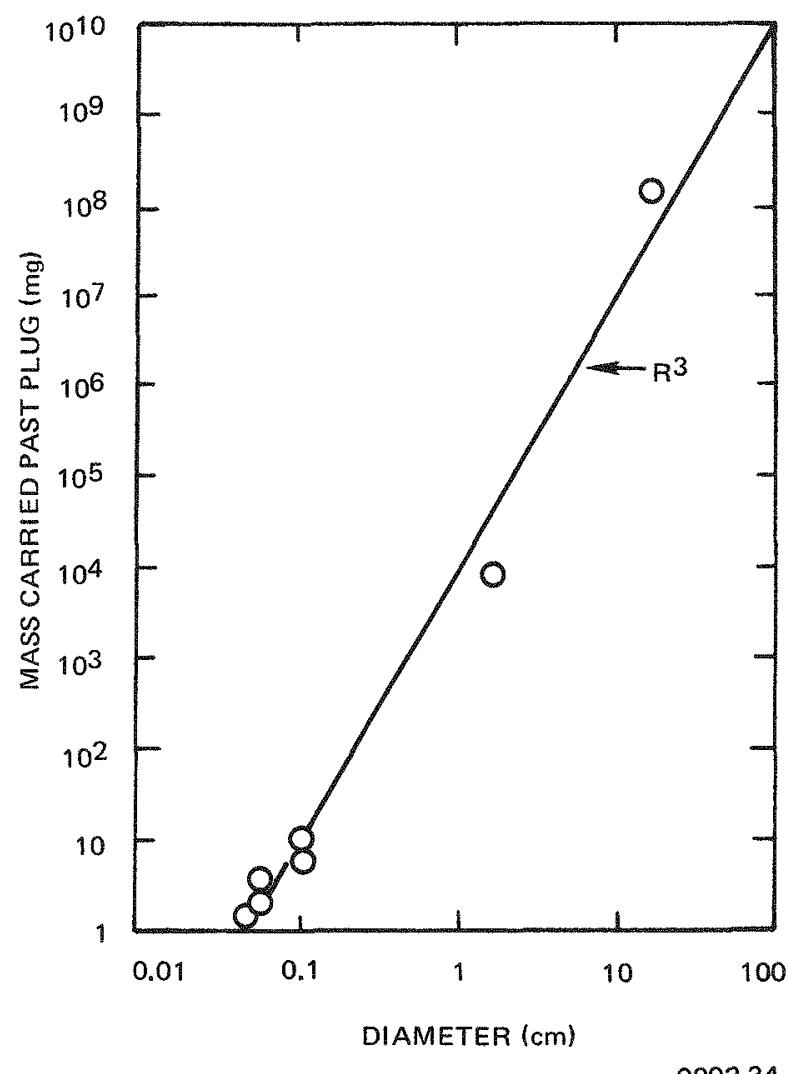

Figure 3. Data on Plugging Mass vs Duct Size

\section{B. SUBTASK D - HIGH TEMPERATURE-CONCENTRATION AEROSOLS}

The high temperature-concentration aerosol (HTCA) tests conducted to date have been designed to simulate the conditions within a gas bubble caused by an HCDA in an LMFBR system. Estimates have been made of the initial HCDA bubble temperatures and aerosol concentrations, i.e., 3000 to $4000^{\circ} \mathrm{C}$ gas temperature and $2-3 \times 10^{3} \mathrm{~g} / \mathrm{m}^{3}$ aerosol concentration. The tests conducted in 
the HTCA test series have used sodium oxide aerosols to simulate the $\mathrm{UO}_{2}{ }^{-}$ $\mathrm{PuO}_{2}-\mathrm{Na}$ aerosols produced in an HCDA. Preheated sodium is sprayed into the HTCA test apparatus under high atomization gas pressure and allowed to rapidly burn in an oxygen-rich atmosphere to form a sodium peroxide aerosol. Due to the rapid sodium burning, gas temperatures exceeding $2000^{\circ} \mathrm{C}$ and aerosol concentrations approaching $1 \times 10^{3} \mathrm{~g} / \mathrm{m}^{3}$ have been obtained. These test conditions provide an adequate base on which to characterize the behavior of the aerosols.

The Laboratory Test Chamber (LTC) has been used as an expansion vessel during the HCTA testseries. The LTC is coupled to the HTCA test apparatus through a $1.2-\mathrm{cm}$ diameter pipe fitted with a series-mounted ball and sliding gate solenoid valve. At the completion of the HTCA sodium injection period, indicated by a rapid drop in test apparatus gas pressure, the connecting valves are opened and $\sim 6$ to 10 liters of HTCA gas is transferred to the LTC, thereby diluting the aerosols by a factor of 1:400. The aerosols which are also transferred to the LTC are subsequently analyzed for concentration. Fallout slides placed on the floor of the LTC provide a means of determining the initial aerosol size. For all HTCA tests where the maximum aerosol concentration exceeded $150 \mathrm{~g} / \mathrm{m}^{3}$, large agglomerates ranging in size from 100 to $250 \mu \mathrm{m}$ diameter were observed on the LTC fallout slides. From these data it is postulated that the aerosols in the HTCA test apparatus rapidly agglomerate in a short time period, then are subject to removal by plateout and fallout. Aerosol size measurements, obtained $\sim 25$ to $30 \mathrm{~s}$ after the spray period, show that at that time only aerosols in the $1-4 \mu \mathrm{m}$ range exist.

An improved internal wall plateout and floor fallout aerosol sampling device has been developed and installed in the HTCA test apparatus. This sampling device is comprised of two wall plateout stations and a single floor fallout station The surfaces to be exposed to the vessel atmosphere during a test consist of 16 each removable tabs which are positioned under a shield canopy. Upon actuation of the sampling device drive motor, these tabs are withdrawn from under the respective wall or floor shield canopies at the rate of $2.6 \mathrm{~s} / \mathrm{tab}$. The tabs are removed from the test vessel at the completion of a test and analyzedfor aerosol plateout or fallout deposition. Figure 4 is a photograph showing a typical fallout or plateout sampling device. In the figure, alternate tabs have been removed from the main slide for demonstration. 


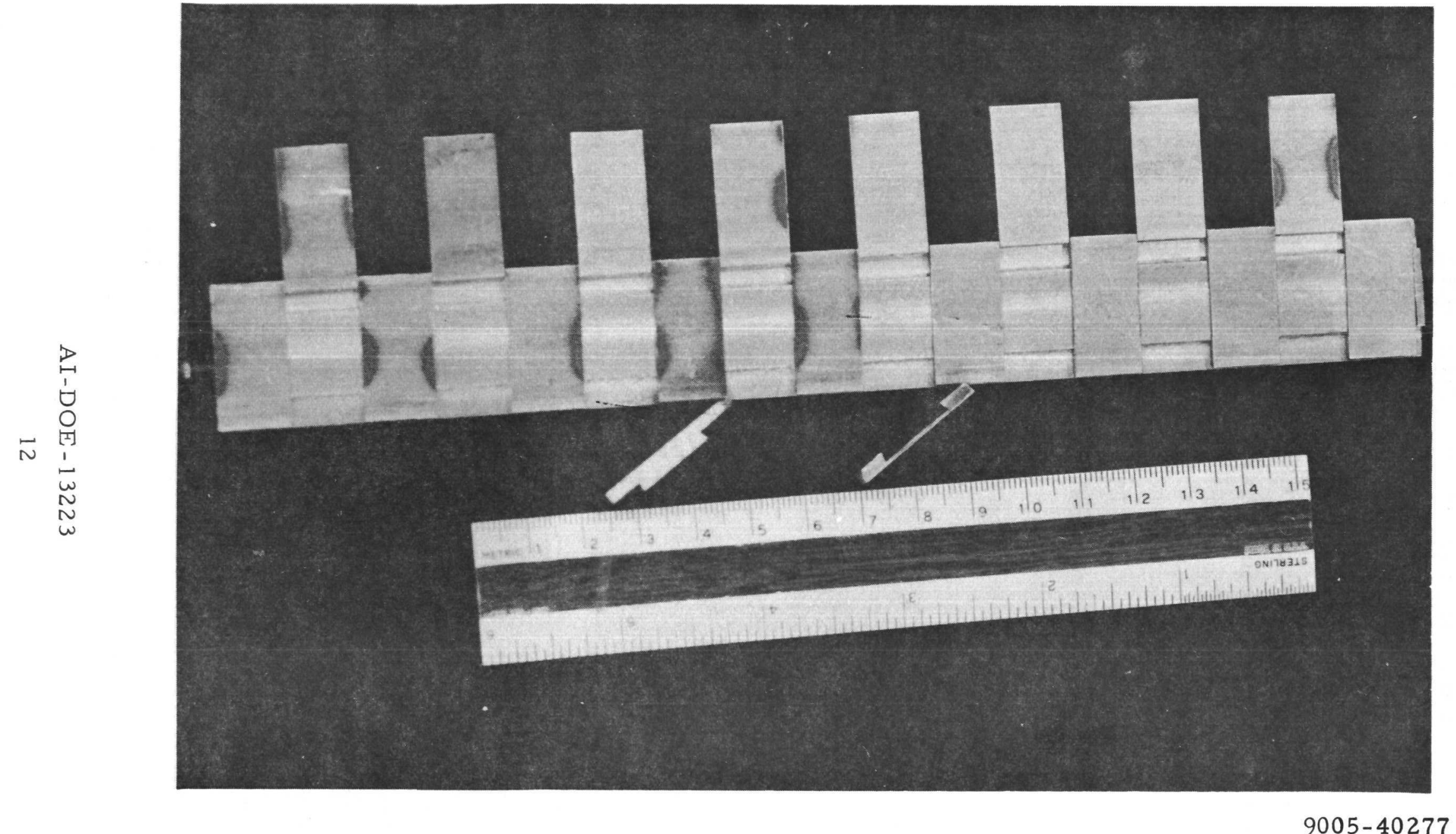

Figure 4. HTCA Plateout and Fallout Sampling Device 
The HTCA aerosol plateout and fallout histories previously reported ${ }^{(1)}$ were incorrectly labeled. This figure is correctly shown here as Figure 5. Operational checkout of the improved internal plateout and fallout sampling device was made on HTCA Test No. 21. Although little quantitative data were obtained during the test due to failure of a slide-gate valve located on one of the aerosol sizing sampling ports, some qualitative fallout and plateout data were obtained. During the test, the fallout and plateout sampling device was actuated at the beginning of the sodium spray period. This allowed measurements to be taken both during and after the spray. Post-test analysis showed that a fraction of the available aerosols were removed due to impaction on the test apparatus walls and floors. It is expected that from the additional experimental data obtained with the improved fallout and plateout sampling device, complete time-dependent aerosol histories can be obtained on future HTCA tests.

\section{SUBTASK F - LARGE SCALE MOLTEN FUEL TESTS \\ 1. Introduction}

A facility has been constructed for arc melting and pouring large quantities (up to $100 \mathrm{~kg}$ ) of $\mathrm{UO}_{2}$ or steel for use as simulants for the debris which might result from a reactor accident.

Melting takes place within a large water jacketed tank (Figure 6). The melting crucible is water cooled copper about $25 \mathrm{~cm}$ in diameter and $20 \mathrm{~cm}$ deep. The crucible has a layer of solid stainless steel on the bottom. The melt is heated by a high current arc which passes from a graphite electrode to the $\mathrm{UO}_{2}$ surface and then through the $\mathrm{UO}_{2}$, the stainless steel, to the copper crucible. Some $\mathrm{UO}_{2}$ remains frozen in a skull next to the copper or stainless steel while the remainder in the center is melted by the arc.

The several uses of the molten $\mathrm{UO}_{2}$ and steel are to: (1) study the production, agglomeration, and dispersal of fuel and sodium aerosols, (2) test the interaction of molten material with sodium, particularly in regard to any mechanism which might produce overpressure, (3) determine the rate of meltthrough of the reactor vessel, underlying concrete, and/or sacrificial material used to retard melt-through, (2) study methods of post-accident heat removal, 


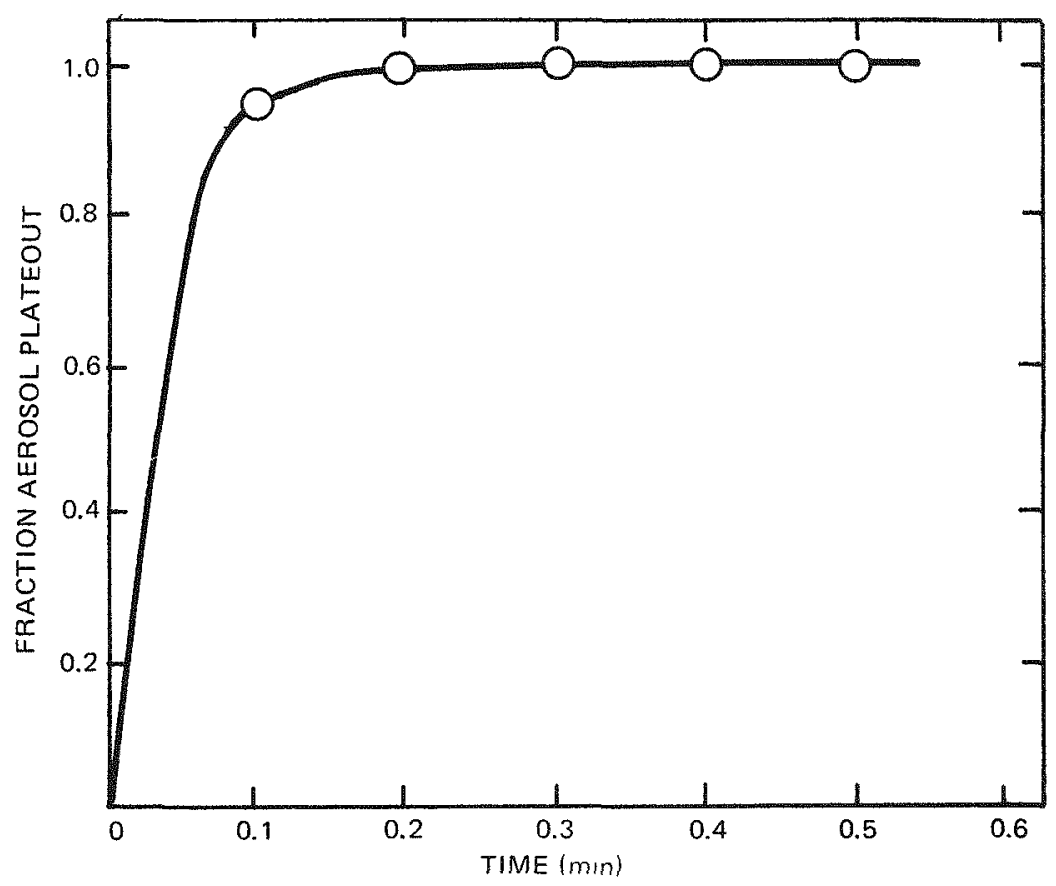

a. HTCA AEROSOL PLATEOUT HISTORY

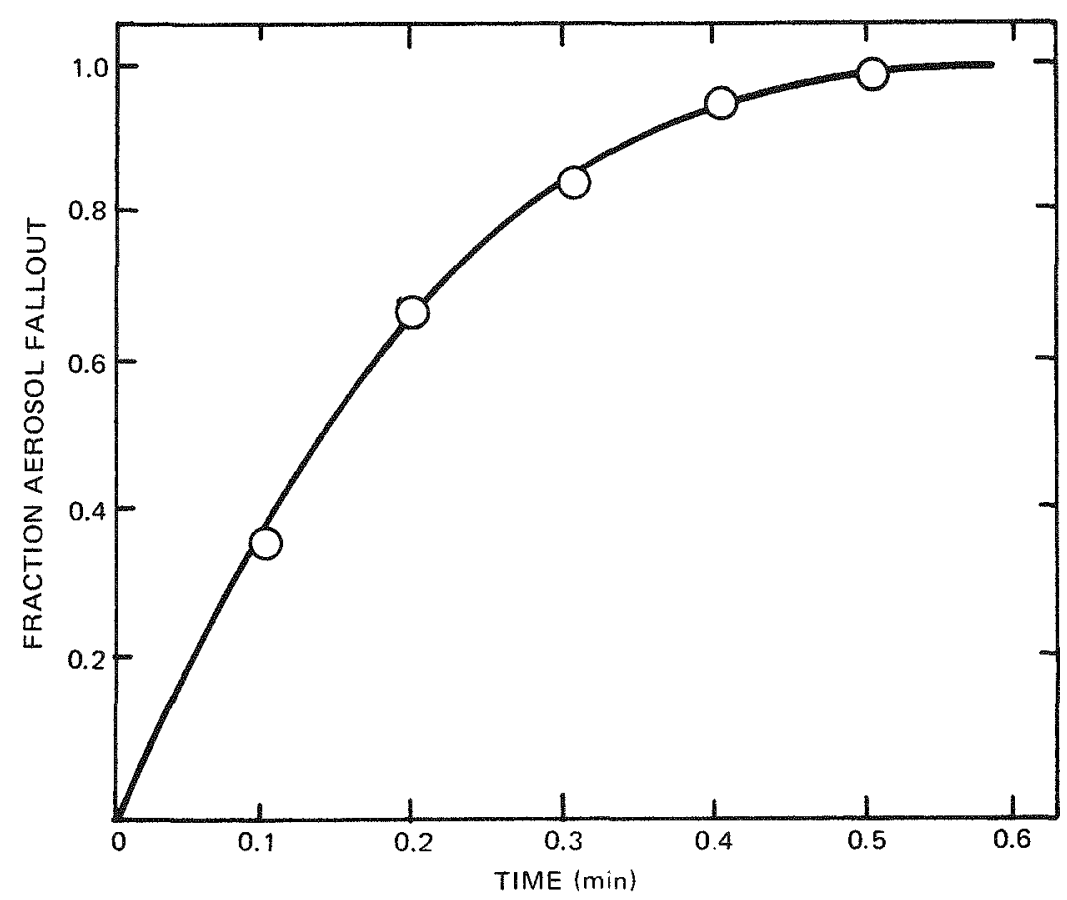

b. HTCA AEROSOL FALLOUT HISTORY

$9005-40291 \mathrm{~A}$

Eigure 5. Typical HTCA Aerosol Histories 


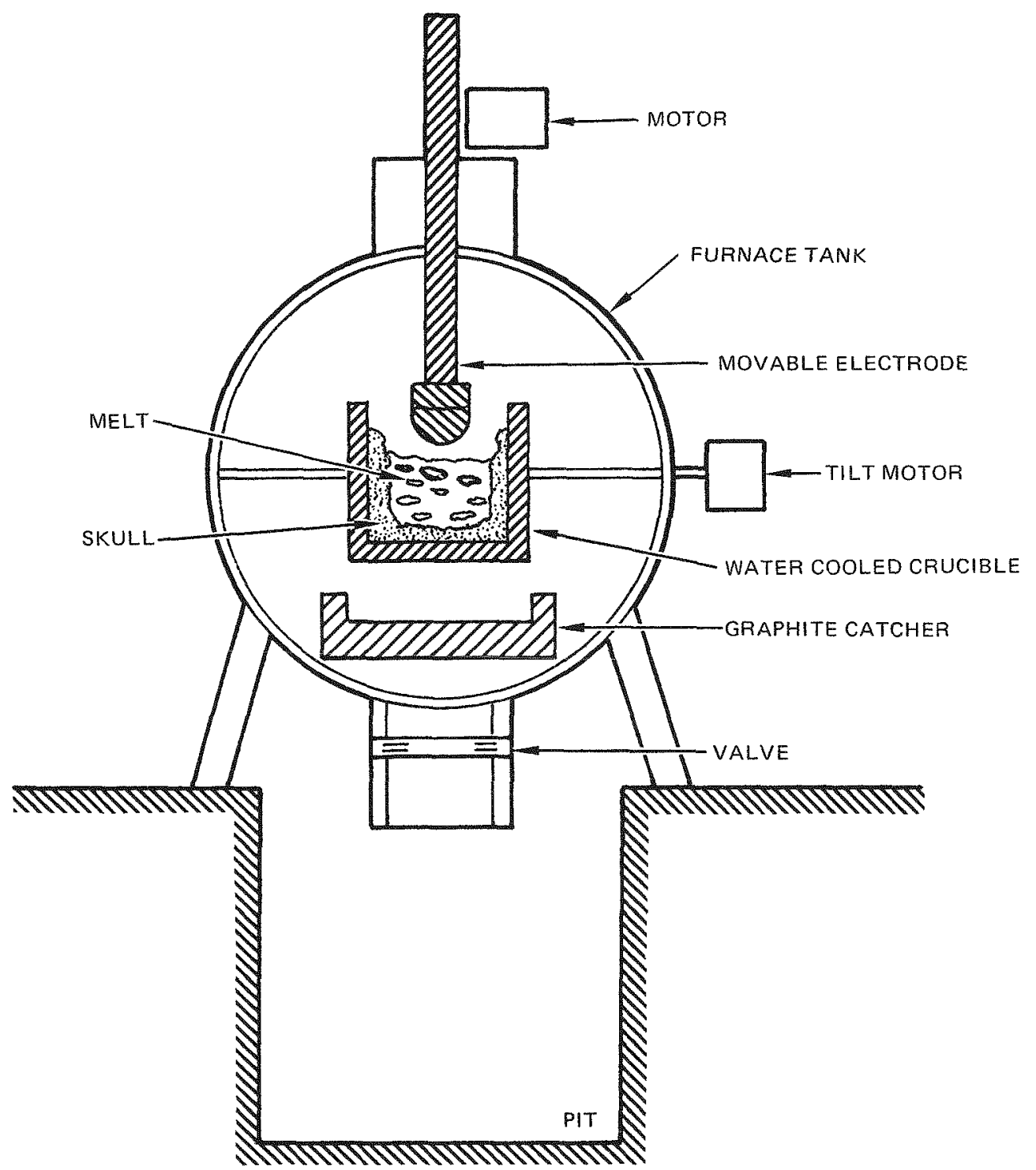

9092-35

Figure 6. Arc Melting Furnace 
and containment rupture problems in general, and (5) test the effect of the presence of fiasion products (using stable isotopes) in any of the above.

During the past quarter, several melts and pours of $\mathrm{UO}_{2}$ have been made onto graphite and ordinary steel plate. In one instance $15 \mathrm{~kg}$ of $\mathrm{UO}_{2}$ was melted and poured onto a steel plate. The molten $\mathrm{UO}_{2}$ exhibited a low viscosity and spread out in an even layer on the plate without melting the steel except at one edge. This test demonstrated the fluidity of molten $\mathrm{UO}_{2}$ and its tendency to spread out into a configuration favoring rapid heat transfer.

2. Melting Procedure

A 10-cm layer of stainless steel was first melted in the bottom of the crucible. (A large temperature gradient develops across the stainless steel and allows the solid $\mathrm{UO}_{2}$ in the crucible bottom to be hot enough to conduct electricity. Then, sintered $\mathrm{UO}_{2}$ pellets were placed on top of the stainless steel and melted several times so as to eliminate the interpellet voids.

As a final step, the electrode was withdrawn, and the molten content of the crucible was quickly poured onto a plate below. The height of the pour varied between $56 \mathrm{~cm}$ and $25 \mathrm{~cm}$ as the crucible was tipped. Figure 7 is a photograph of the graphite electrode and the tipped crucible after pouring. Note the tilted crust on surface of the central region. Some "icicles" of $\mathrm{UO}_{2}$ are seen extending over the edge. The stainless steel fragments shown on the crucible edge and on the catcher below were parts of rods originally placed across the crucible to serve as temporary electrodes to start the arc. This procedure was necessary because $\mathrm{UO}_{2}$ is effectively an insulator below $\sim 600^{\circ} \mathrm{C}$. Some erosion of the graphite electrode can be seen at the top of Figure 7 since the electrode had a rounded end when new.

The melting process required $\sim 75 \mathrm{~min}$. During this time, the current was slowly increased so as to evenly heat the crucible contents. At times, heavy smoke appeared and reduced the visibility of the surface. The current was then decreased until the smoke cleared. Fresh argon was continuously bled into the furnace tank and the excess gas pumped away through an automatic pressure regulator valve which maintained the argon pressure at 0.5 atm. The argon temperature increased to about 400 to $500^{\circ} \mathrm{C}$ during the melting. After 
pouring, the furnace and melt were allowed to cool and the furnace was evacuated and backfilled with air.

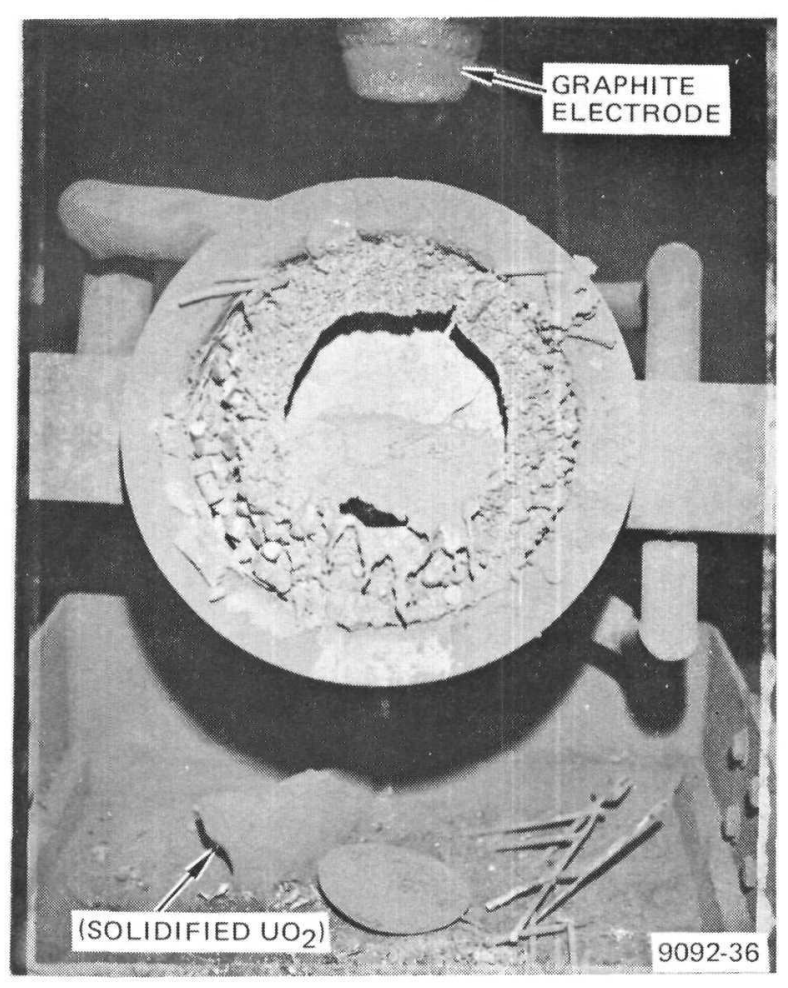

Figure 7. Crucible After Pouring $\mathrm{UO}_{2}$

\section{Results of Pours Onto Graphite}

Tests $\mathrm{A}$ and $\mathrm{B}$ consisted of two pours of molten $\mathrm{UO}_{2}(4.8$ and $14.2 \mathrm{~kg})$ onto a flat graphite surface. In both cases, the $\mathrm{UO}_{2}$ poured without splattering through argon gas and froze into a pancake shape upon contact with the graphite. Little or no chemical reaction took place because the graphite quickly conducted the heat away from the spread out $\mathrm{UO}_{2}$.

Figures 8 and 9 show the top and bottom of the solidified $\mathrm{UO}_{2}$ after Test $\mathrm{B}$. Some stainless steel rods can be seen protruding from the melt. These rods were used to start the arc and probably fell from the crucible edge. During cooling, the $\mathrm{UO}_{2} \mathrm{cracked}$ into several pieces, and these are shown on edge in Figure 10. The pour shape was roughly rectangular, 22 by $23 \mathrm{~cm}$ by $2.5 \mathrm{~cm}$ thick. The density of two small pieces was measured by weighing in air and under water. The measured density was 9.84 and $9.92 \mathrm{~g} / \mathrm{cc}$. (The theoretical density of $\mathrm{UO}_{2}$ is $10.96 \mathrm{~g} / \mathrm{cc}$.) 


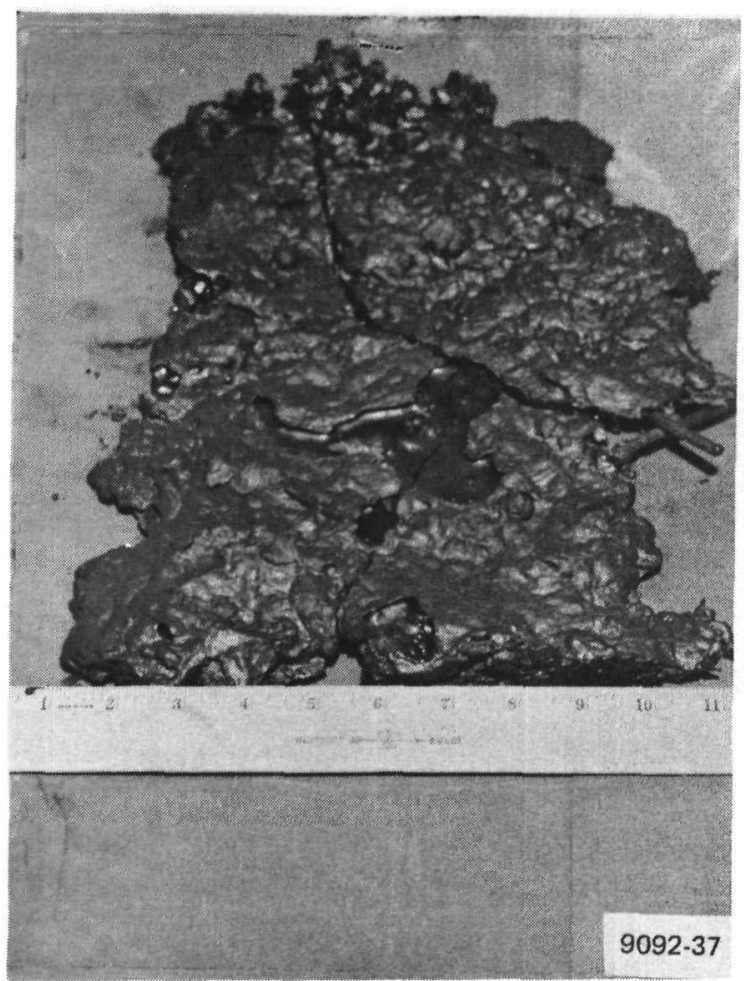

Figure 8. Solidified $\mathrm{UO}_{2}$
Top View (Test B)
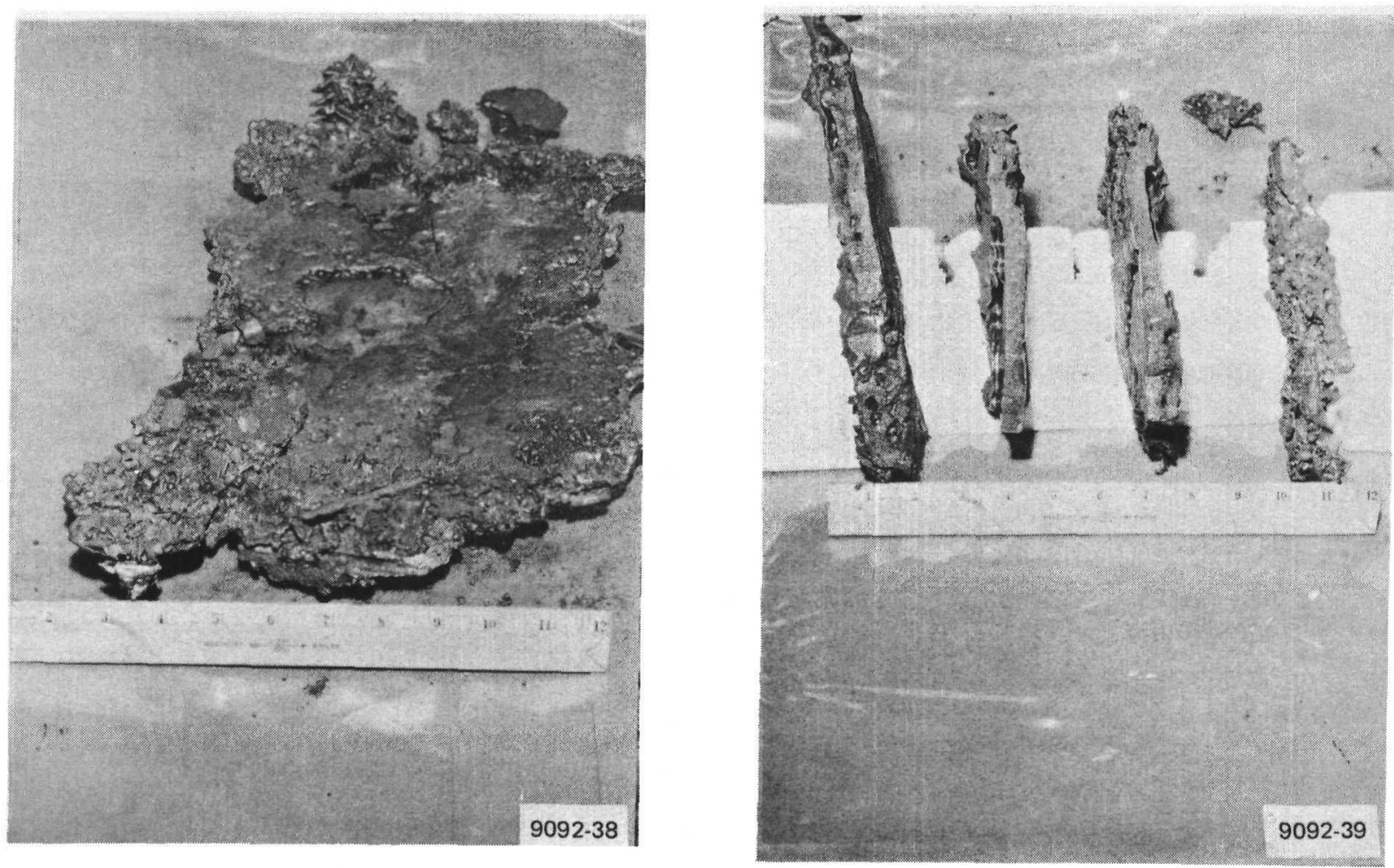

Figure 9. Solidified $\mathrm{UO}_{2}$ Bottom View (Test B) Figure 10. Solidified $\mathrm{UO}_{2}$
Edge View (Test B) 


\section{Results of Pours Onto Carbon Steel}

In Tests $C$ and $D$ a $50-\mathrm{cm}$ by $46-\mathrm{cm}$ by $0.64-\mathrm{cm}$ thick carbon steel plate was placed so that the $\mathrm{UO}_{2}$ poured onto the center of the plate. The plate was separated from a graphite-lined pan underneath by $2.5-\mathrm{cm}$ thick graphite blocks placed at each corner. Figure 11 shows the results of Test C. After the pour, $12.2 \mathrm{~kg}$ of $\mathrm{UO}_{2}$ remained frozen as a $0.6 \mathrm{~cm}$ layer on the plate, and $3.0 \mathrm{~kg} \mathrm{ran}$ over the edge. Figure 12 shows the plate after the frozen $\mathrm{UO}_{2}$ layer was removed. No melting of the plate was apparent except for the two small areas near one edge where the $\mathrm{UO}_{2}$ ran over and under the plate. Here the molten $\mathrm{UO}_{2}$ formed a sandwich around the plate. (The hole shown in the plate was originally present and some $\mathrm{UO}_{2}$ flowed through it.) The plate was slightly warped by uneven heating. Similar results were observed in Test D.

An interesting result of Tests $C$ and $D$ was the small amount of damage to the steel plate. (A similar result has been reported in Reference 6.) Only two small regions near the plate edge were melted even though the $\mathrm{UO}_{2}$ remaining on the plate originally contained sufficient enthalpy ${ }^{*}$ to extensively melt the steel, not considering any heat lost by radiation. A transient thermal analysis is made in the following section.

\section{Thermal Analysis of Pour Onto Carbon Steel}

After $\mathrm{UO}_{2}$ contacts and runs over a metal sheet, it begins to cool by radiation from the upper surface and by direct conduction to the sheet. The molten $\mathrm{UO}_{2}$ forms a crust on the upper side and lower sides as shown in Figure 13. Heat is supplied as the $\mathrm{UO}_{2}$ yields up the latent heat of fusion. Finally, the crust grows in size from both sides until it meets in the center.

*The enthalpy difference of molten $\mathrm{UO}_{2}$ at $3100^{\circ} \mathrm{K}$ is about $1.4 \times 10^{3} \mathrm{j} / \mathrm{g}$ with respect to the melting point of steel (1700' $\mathrm{K})$. Thus, the $12.1 \mathrm{~kg}$ of $\mathrm{UO}_{2}$ remaining on the plate after the pour could provide $1.2 \times 107 \mathrm{j}$ to heat the plate and melt it. To melt steel at $1700^{\circ} \mathrm{K}$ requires about $1000 \mathrm{j} / \mathrm{g}$. As the steel. plate weighs $12 \mathrm{~kg}, 1.3 \times 10 \mathrm{j}$ would completely melt it, roughly the amount of heat available. Thus, if there had been good heat transfer, the steel plate would have extensively melted. 


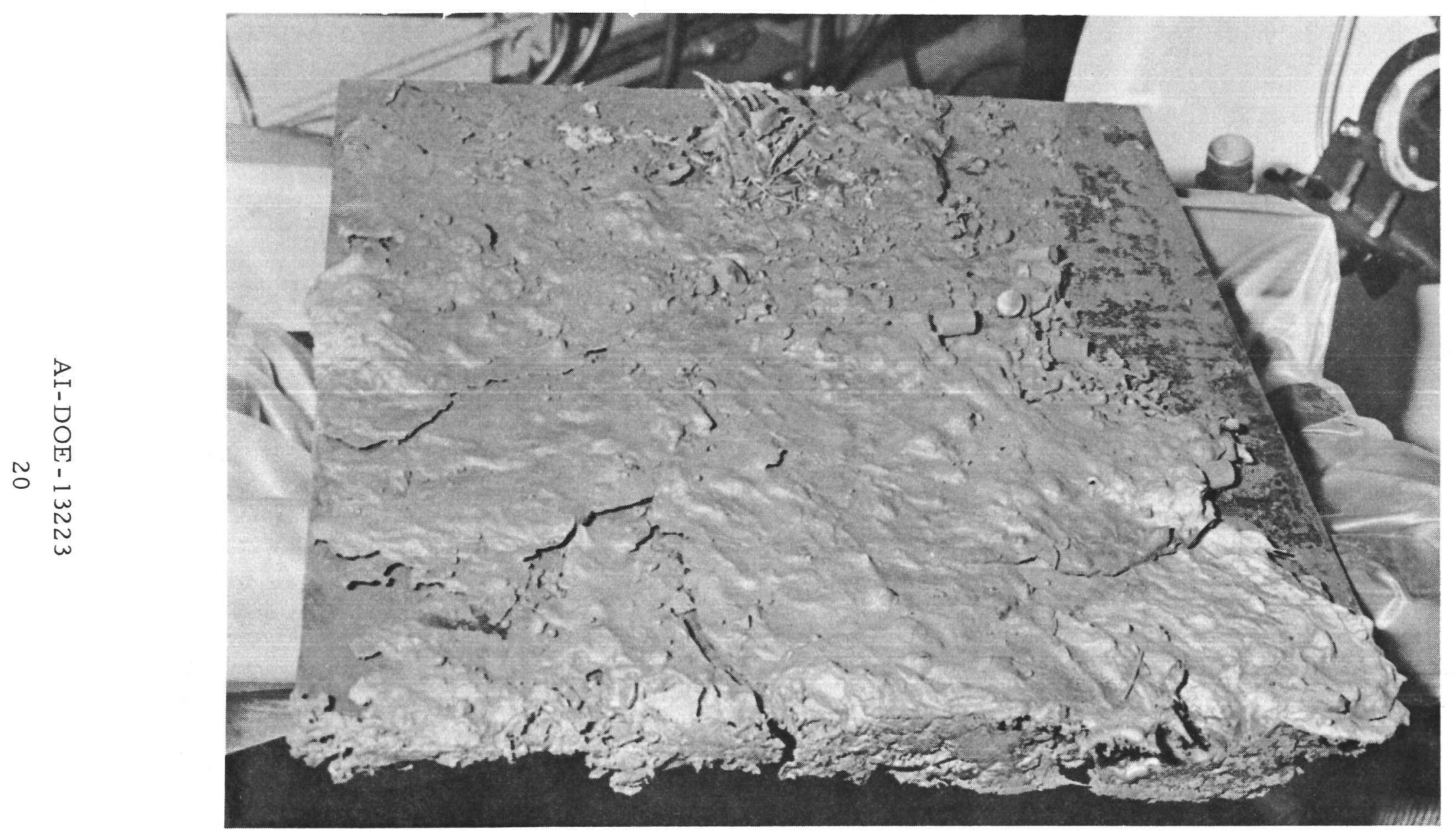

$9005-40305$

Figure 11. Frozen $\mathrm{UO}_{2}$ Layer on Carbon Steel Plate 


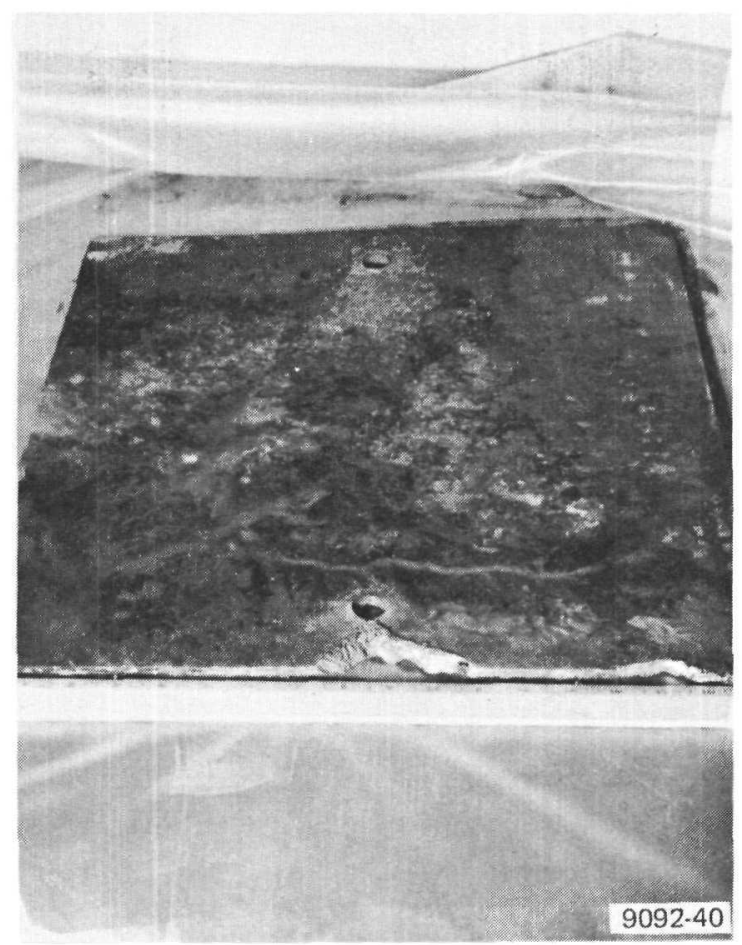

Figure 12. Plate After $\mathrm{UO}_{2}$ Removal (Test C)

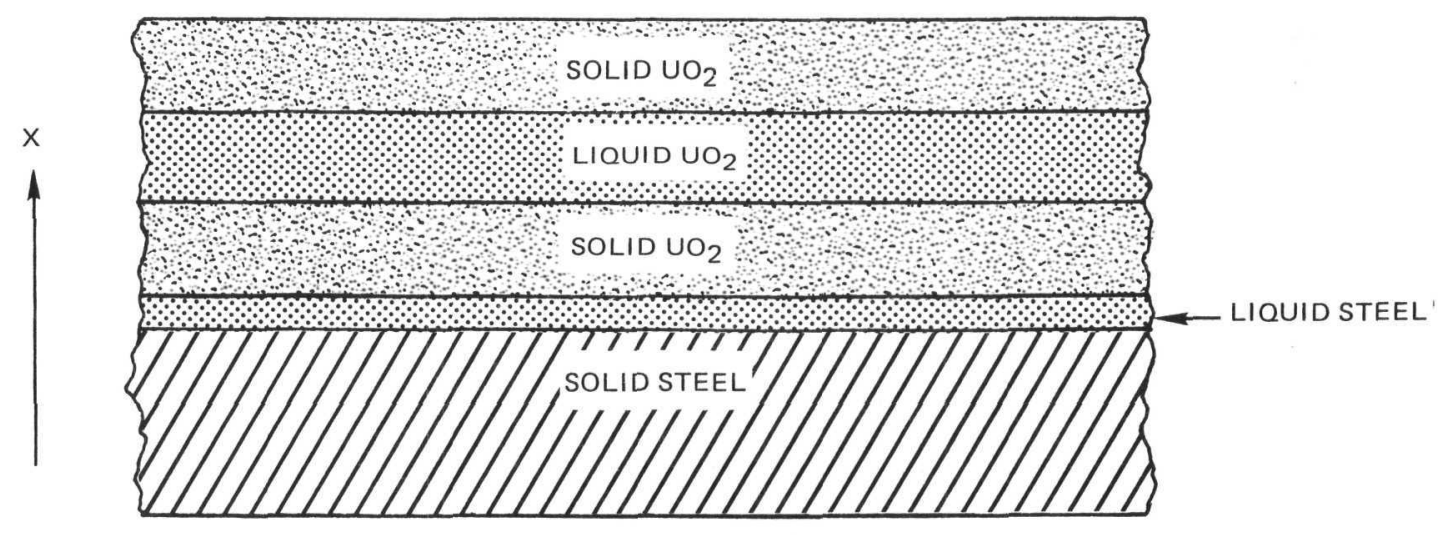

9092-41

Figure 13. $\mathrm{UO}_{2}$ Freezing on a Steel Plate (Model for thermal analysis using TAP-4 Code) 
TABLE I

INPUT PARAMETER FOR TAP-4F CODE

\begin{tabular}{|c|c|c|c|c|}
\hline \multirow{4}{*}{ 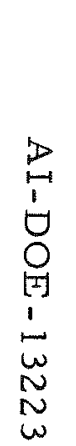 } & & Steel & Solid $\mathrm{UO}_{2}$ & Liquid $\mathrm{UO}_{2}$ \\
\hline & Melting Point $\left({ }^{\circ} \mathrm{C}\right)$ & 1430 & 2860 & \\
\hline & Initial Temperature $\left({ }^{\circ} \mathrm{C}\right)$ & 100 & & 3000 \\
\hline & Thermal Conductivity (cal/cm-s-K) & $0.0298+3.85 \times 10^{-3} \mathrm{~T}$ & $\begin{array}{l}2.5 \times 10^{-9} \mathrm{~T}^{2}-9.21 \times 10^{-6} \mathrm{~T} \\
+0.0152\end{array}$ & 0.0245 \\
\hline$\underset{\omega}{N}$ & Specific Heat (cal/g) & 0.12 & $\begin{array}{l}2.49 \times 10^{-8} \mathrm{~T}^{2}-3.43 \times 10^{-5} \mathrm{~T} \\
+0.0746\end{array}$ & 0.12 \\
\hline & Slab Thickness $(\mathrm{cm})$ & 0.63 & 0.63 & \\
\hline & Density $\left(\mathrm{g} / \mathrm{cm}^{3}\right)$ & 8.0 & 9.8 & 8.5 \\
\hline
\end{tabular}


The governing equation for the one-dimensional slab geometry is as follows:

$$
\frac{\partial T_{i}}{\partial t}=\alpha_{i} \frac{\partial^{2} T_{i}^{2}}{\partial x^{2}},
$$

where

$$
\begin{aligned}
i & =1 \text { for molten phase } \\
i & =2 \text { for solid phase } \\
T_{i} & =\text { temperature }\left({ }^{\circ} \mathrm{K}\right) \text { of phase } i \\
t & =\text { time }(\mathrm{s}) \\
\alpha_{i} & =\text { thermal diffusivity of phase } i
\end{aligned}
$$

The phase change boundary condition which represents the movement of the zone of solidification is:

$$
K_{1} \frac{d t_{1}}{d x}=K_{2} \frac{d t_{2}}{d x}=\Delta H_{f} \rho \frac{d x(t)}{d t}
$$

where

$$
\begin{aligned}
\Delta \mathrm{H}_{\mathrm{f}} & =\text { heat of fusion of } \mathrm{UO}_{2} \\
\mathrm{~K}_{1}, \mathrm{~K}_{2} & =\text { thermal conductivity of molten, solid phase }
\end{aligned}
$$

Initial conditions are: $T_{i}=T_{i}(0)$ at $t=0$.

These equations may be solved numerically using a computer code called TAP-4. (7) $^{2}$ The $\mathrm{UO}_{2}$ region is divided into Regions 2 to 21 and the steel into Regions 22 to 42 . Time steps of $0.005 \mathrm{~s}$ were taken. The input parameters for two phases of molten $\mathrm{UO}_{2}$ and for steel are given in Table 1.

Figure 14 shows the result of one computer run. The calculation shows that the steel temperature will reach the melting point if the $\mathrm{UO}_{2}$ has zero porosity and thus, the maximum thermal conductivity. If the thermal conductivity of the $\mathrm{UO}_{2}$ is reduced by $16 \%$ porosity, the calculation indicates that the steel will not melt. The steel temperature almost reached the melting point. In the experiment, the steel did not melt except at the edge where there was a thick 


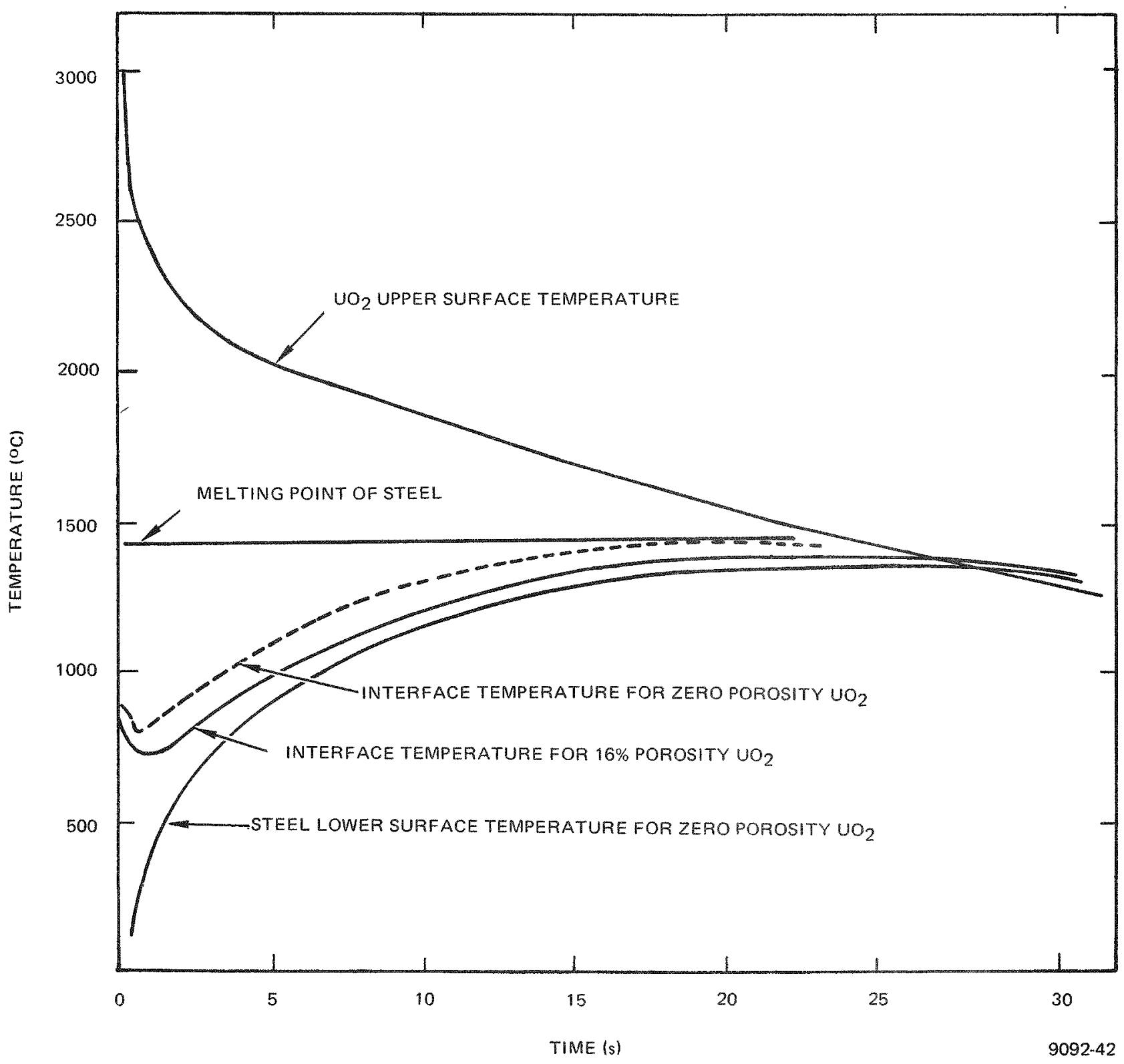

Figure 14. Temperature vs Time After Contact (TAP-4 Simulation) 
layer of $\mathrm{UO}_{2}$ surrounding it. Actually, the maximum temperature of the steel must have been $200^{\circ}$ or more below its melting point as the steel plate did not sag even though it was supported at the four corners by small blocks of graphite.

\section{Conclusions}

Tests $C$ and $D$ seem to indicate that even relatively thin layers of steel could potentially provide considerable protection against immediate meltthrough from molten $\mathrm{UO}_{2}$ fuel on a steel-lined reactor cavity. The fuel would quickly spread out evenly into a more coolable configuration (with higher radiation losses) without necessarily penetrating the liner. These questions of insulation at the steel- $\mathrm{UO}_{2}$ interface, radiation losses from the $\mathrm{UO}_{2}$, and other heat transfer related problems will be the subject of further detailed investigations using the TAP 4 Code.

\section{NEXT REPORT PERIOD ACTIVITIES}

A multiple bend leak path representing a leaking reactor head seal will be built. Attentuation tests will be tested using particulate concentrations of $\sim 40$ and $500 \mathrm{~g} / \mathrm{m}^{3}$, with pressure differentials of 0.7 and $2 \mathrm{~atm}$, respectively.

Studies of particulate attenuation through straight capillaries will continue.

The high temperature-concentration aerosol tests to be conducted during the next period will emphasize collection of experimental data to determine the time-dependent fallout and plateout of aerosols during a test. Preparations are being made to modify the incremental fallout and plateout sampling device to obtain these data.

The tests to be performed at the arc melt test facility will include melting larger and larger quantities of $\mathrm{UO}_{2}$ and pouring this melt onto stainless steel, ceramic and concrete samples.

\section{REFERENCES}

1. "Annual Technical Progress Report, LMFBR Safety Program, GFY 1977," AI-DOE-13210 (1977) 
2. T. C. Huang, "Review and Development of Aerosol Analytic Methods," GEAP-14147 (September 1976)

3. O. Hubner, E. U. Vaughan, and L. Baurmash, "HAA-3 User Report," AI-AEC-13038 (March 1973)

4. A. E. Stewart, private communication, Atomics International (1977)

5. F. G. Schmidt, private communication, Atomics International (1977)

6. D. G. Swanson, et al., "Interactions Between Molten Core Debris and Core Containment Materials," TANSAO 27, 659 (1977)

7. B. J. Dray, "Thermal Physics Note 57; Thermal Analysis Program (TAP) User's Manual, Fortran II Version," NAA-SR-TDR-11812 (January 11 , 1966) 